\title{
Propolis consumption ramps up the immune response in honey bees infected with bacteria
}

\author{
Aline Patricia Turcatto ${ }^{1}$, Anete Pedro LourençO ${ }^{2}$, David De Jong ${ }^{1}$ \\ ${ }^{1}$ Genetics Department, Ribeirão Preto Medical School, University of São Paulo, Ribeirão Preto, SP, Brazil \\ ${ }^{2}$ Department of Biological Sciences, School of Biological and Health Sciences, Federal University of Jequitinhonha and \\ Mucuri Valleys, Diamantina, MG, Brazil
}

Received 15 February 2017 - Revised 17 September 2017 - Accepted 9 October 2017

\begin{abstract}
Among their natural defenses against pathogens and parasites, honey bees coat nest cavity surfaces with propolis. Consequently, they are able to economize on immune system activation, lowering energetic costs and improving longevity. However, the mechanisms through which propolis acts to protect bees are unknown. Here we show that $0.1 \%$ propolis fed in a pollen substitute diet greatly increases activation of antimicrobial peptide genes (defensin-1, abaecin, hymenoptaecin, and apidaecin) in bees injected with Escherichia coli, compared to infected bees fed the same diets without propolis. This increase was not seen in uninfected bees fed propolis. In addition to its protective role in the hive, propolis stimulates high-level expression of the immune system response in bees challenged with microorganisms. Whether this increase translates into improved disease control will require laboratory and field tests with pathogens.
\end{abstract}

\section{Apis mellifera / antimicrobial peptides / pollen substitute / gene expression / bee health}

\section{INTRODUCTION}

In recent years, large-scale honey bee colony decline has impacted on the costs and yields of numerous crops that require their pollination services (Chopra et al. 2015; Bauer and Wing 2016). The phenomenon of large-scale bee losses has been labeled "colony collapse disorder" (CCD); however, attributing the majority of such losses to CCD is probably an oversimplification of the problems involved. Losses have been linked to various causes, including the stress of transporting colonies long distances to crops, mite parasites, viruses, microsporidians, fungi, pesticides, and inadequate food sources (vanEngelsdorp et al. 2009; Neumann and Carreck 2010). Bees need an adequate protein source in order to achieve high-level expression of antimicrobial immune

Corresponding author: D. De Jong,

ddjong@fmrp.usp.br

Handling editor: David Tarpy system genes (Alaux et al. 2010). In their efforts to avoid losses and produce colonies suitable for pollination services, beekeepers have greatly increased their investment per colony, including heavy feeding of pollen substitutes, often mixed with putative health products (DeGrandi-Hoffman and Chen 2015). These "health products," such as essential oils, are frequently included in bee diet formulations (Imdorf et al. 1999), though it is difficult to objectively determine whether their use actually improves bee health and is worth the investment.

Though honey bees have considerably fewer immune genes than many other insects (Evans et al. 2006), they apparently compensate with a unique set of defenses, which have been denominated as "social immunity," to protect themselves against pathogens and pests. These include mechanical removal of parasites, eviction of infected individuals, garbage removal, and nest protection with propolis (Cremer et al. 2007; Evans and Spivak 2010; Visscher 1980; Wilson-Rich 
et al. 2009). Propolis is made from resins with antimicrobial properties that honey bees collect from plants. Bees use it to coat hive surfaces, helping prevent the wood of tree cavities from rotting, to close large openings for protection and to avoid excessive air circulation, to seal cracks and crevices, to protect against pests and parasites that may otherwise harbor in such spaces, and to reinforce the wax combs (Seeley and Morse 1976; Simone-Finstrom and Spivak 2010; Visscher 1980). For beekeepers, however, propolis has traditionally been considered a nuisance, as frames containing combs with brood and honey and other hive parts are glued together with this material and are hard to remove without prying with a hive tool, angering the bees and frequently resulting in breakage of hive parts and combs. Propolis also sticks to beekeeper's gloves and can dirty and darken comb, making comb honey less attractive. Dark combs result in darkened extracted honey, which has reduced market value. As a result, bee breeding efforts have traditionally selected against propolis production, with unknown consequences for bee health (Morse 1975; Simone-Finstrom and Spivak 2010). Perhaps not coincidentally, Africanized honey bees, which produce considerable propolis, are known to be relatively resistant to bee diseases and parasites; however, pest and disease resistance in Africanized bees is probably due to a combination of many factors, including intense hygienic behavior, grooming and small brood comb cell size (De Jong 1996; Rosenkranz 1999).

Propolis in the hive as a kind of protective envelope has been associated with reduced expression of immune system genes (Borba et al. 2015; Simone et al. 2009), apparently as an energy saving mechanism, because its presence in the hive would make activation of these genes unnecessary due to the inhibition of microbial growth by propolis. Overexpression of immune genes has costs for the bees and reduces colony productivity (Evans and Pettis 2005; Mallon et al. 2003; Moret and Schmid-Hempel 2000). Based on their understanding that propolis in the hive improves bee health, some beekeepers add it to their pollen substitute formulations, though data is lacking concerning whether it is beneficial when fed in this way. To better understand how propolis impacts on honey bee health and how this material could be exploited, we examined its effect on the immune system when fed orally to bees challenged with bacteria.

\section{MATERIALS AND METHODS}

\subsection{Bees and treatments}

Africanized Apis mellifera were collected from hives of the experimental apiary of the Department of Genetics, Ribeirão Preto Medical School, University of São Paulo. Frames of sealed brood were kept in an incubator $\left(34^{\circ} \mathrm{C}, 80 \%\right.$ relative humidity), where worker bees emerged. Newly emerged worker bees (0-16-h-old) from three different colonies were mixed and randomly separated into six groups of 100 individuals for each of the four test conditions (two diets, with or without propolis). The bees were confined in plastic screened cages $(21.5 \mathrm{~cm} \times 13 \mathrm{~cm} \times 13 \mathrm{~cm})$, where they were maintained in an incubator during 7 days at $30^{\circ} \mathrm{C}$ and $80 \% \mathrm{RH}$. During this period, the bees were fed on one of two artificial protein diets, with or without propolis extract. Water was given ad libitum to all groups. After this period of feeding, the bees were individually injected with $1 \mu \mathrm{L}$ of live Escherichia coli $\left(10^{6} \mathrm{bac} \mathrm{mL}^{-1}\right)$, or were not injected (uninfected), and were maintained in separate cages. This methodology was chosen (injection of $E$. coli) because it triggers the immune response, causing activation of the antimicrobial peptide genes, with a maximum increase $12 \mathrm{~h}$ after $E$. coli injection (Casteels-Josson et al. 1994). The injections were made using a Hamilton micro syringe (1701LT) with a G30 needle (Lourenço et al. 2013). Bees were collected for analysis at $12 \mathrm{~h}$ after treatment.

\subsection{Diets}

Two different protein-rich diets were fed to the bees: MegaBee ${ }^{\circledR}$ (Megabee, Paso Robles, CA, U.S.A.), a commercial diet widely used in the U.S.A., and a diet based on ingredients locally available in Brazil. Megabee (80 g) was mixed with $20 \mathrm{~mL}$ sucrose syrup $(50 \% \mathrm{w} / \mathrm{w})$ to make a heavy paste. The other diet, which we named Glutenose, consisted of $16 \mathrm{~g}$ soy meal, $12 \mathrm{~g}$ corn 
meal, $6 \mathrm{~g}$ corn gluten meal (called glutenose in Brazil, produced by Cargill), $12 \mathrm{~g}$ sugar cane yeast, $12 \mathrm{~g}$ sucrose (all finely ground), and $42 \mathrm{~mL}$ sucrose syrup $(50 \% \mathrm{w} / \mathrm{w})$. The diets were prepared with and without the addition of Brazilian green propolis extract $(1 \mathrm{~mL}$ propolis extract in $100 \mathrm{~g}$ pollen substitute diet). The propolis extract (10\% propolis solids in an ethanol solution) was obtained from a local company (Apis Flora, Ribeirão Preto, SP, Brazil) that produces ISO9001-quality propolis products for national and export markets. Fresh diet was provided every 2 days. Consumption was measured when the diets were replaced by subtracting the weight of the leftover diet from what had originally been provided. This was done nine times for each diet.

\subsection{RNA extraction and cDNA synthesis}

Total RNA was isolated from abdomens (fat body plus carcass), free from intestine, using TRIzol reagent (Life Technologies). Each sample was prepared with abdomens dissected from three bees. Three samples were collected for each treatment. Samples were treated with DNase (Invitrogen) to eliminate contaminant genomic DNA. For the reverse transcription, we used $3 \mu \mathrm{g}$ of total RNA, Superscript II (Invitrogen) and Oligo $(\mathrm{dT})_{12-18}$ (Invitrogen). Aliquots of cDNA were subjected to real-time PCR.

\subsection{Quantitative real-time RT-PCR}

A qRT-PCR assay was performed using the 7500 Real-Time PCR System (Applied Biosystems). Amplification was carried out in a $20-\mu \mathrm{L}$ reaction volume, containing $10 \mu \mathrm{L}$ of SYBRs Green Master Mix 2× (Applied Biosystems), $1 \mu \mathrm{L}$ of cDNA (diluted $10 \times$ ), $7.4 \mu \mathrm{L}$ of water, and 8 pmol of each genespecific primer. The PCR conditions were $50^{\circ} \mathrm{C}$ for $2 \mathrm{~min}$ and $95^{\circ} \mathrm{C}$ for $10 \mathrm{~min}$, followed by 40 cycles of $95^{\circ} \mathrm{C}$ for $15 \mathrm{~s}$, and $60^{\circ} \mathrm{C}$ for $1 \mathrm{~min}$. The working genes (GenBank accession numbers) and respective primer sequences were: defensin-1 (NM_001011616-: 248-366): forward 5' TGCGCTGCTAACTGTCTCAG3', reverse 5' AATGGCACTTAACCGAAACG3'-3'; abaecin (NW_001252985.1: 236260-236814): forward
5'AGATCTGCACACTCGAGGTCTG3', reverse 5 ' T C G G A T T G A A T G G T C C C T G A 3 ' hymenoptaecin (NW_001259535: 1102-2277): forward 5'CTCTTCTGTGCCGTTGCATA3', reverse 5' GCGTCTCCTGTCATTCCATT3'; and apidaecin (NC_007085: 3974692-3975314): forward 5'CTTTGTAGTCGCGGTATTTGG-3', reverse 5'AGGCGCGTAGGTCGAGTAG3'. All primer sequences were from Siede et al. (2012). Target expression measurements were normalized relative to A. mellifera rpL32 (GenBank accession number AF441189) mRNA levels (Lourenço et al. 2008). The primers used for amplification of this internal control were: forward 5'-CGT CAT ATG TTG CCA ACT GGT-3' and reverse 5'-TTG AGC ACG TTC AAC AAT GG-3'. Data were analyzed according to the comparative threshold cycle $(\mathrm{Ct})$ method, where the amount of a target transcript, normalized to an endogenous reference and relative to a calibrator (an uninfected sample fed on the Megabee diet-M) is given by $2^{-\Delta \Delta C t}$. To check reproducibility, each SYBR green assay was run in triplicate and repeated with three independent samples. Gene expression of $r p L 32$ was similar between untreated and treated bees. We also amplified actin as a reference gene (another suitable reference gene for honey bees, Lourenço et al. 2008). However, in analyzing variation of these genes, rpL32 expression among samples was more stable (NormFinder, stability values $a c t=0.120 ; r p L 32=0.073)$. Thus, we chose $r p L 32$ as the reference gene to analyze our data.

\subsection{Statistical analysis}

Differences in expression levels of antimicrobial peptides between the uninfected and the infected bees of each treatment, as well as between the infected bees fed a protein diet (Megabee or Glutenose) with or without propolis, and between uninfected bees fed Megabee or Glutenose were analyzed by a Wilcoxon signed-ranks test (Daniel 1978). The same test was used to determine if diet consumption varied between diets and for each diet, comparing diet with versus without propolis. A comparison of antimicrobial gene expression (all four genes taken together) before and after injection with bacteria in bees fed the two different diets (with and without propolis) was made with a 
Binomial test (Daniel 1978). Calculations were made R statistics software (R core team 2013).

\section{RESULTS}

We analyzed the expression of genes encoding antimicrobial peptides (AMPs: defensin-1, abaecin, hymenoptaecin, and apidaecin) in caged worker bees fed pollen substitute diets, Megabee or Glutenose, with or without propolis, and later injected or not with $E$. coli . Megabee is a commercial diet, widely used in the USA, and Glutenose is an experimental diet developed with local ingredients in Brazil. Injection with bacteria induced increased AMP expression in all test groups (Fig. 1). The increase was significant for defensin-1 and hymenoptaecin (Wilcoxon $\mathrm{W}=0$, $P<0.05$ ), but not for abaecin and apidaecin (Wilcoxon $\mathrm{W}=2$ and 4 , respectively, $P>0.05$ ) in the bees fed diet without propolis. When propolis was added to the diets, the bees injected with E. coli showed significantly higher up-regulation of all four AMPs compared to infected bees fed with the same diet, but without propolis (Fig. 1; Wilcoxon $\mathrm{W}=0, P<0.05)$.

The Megabee diet induced significantly higher expression of the AMP genes, examined collectively, than did the Glutenose diet in both infected bees and uninfected bees (Binomial test, $P=0.0093)$. When propolis was added, the differences between the Glutenose and Megabee diets in the expression of the four AMP genes in
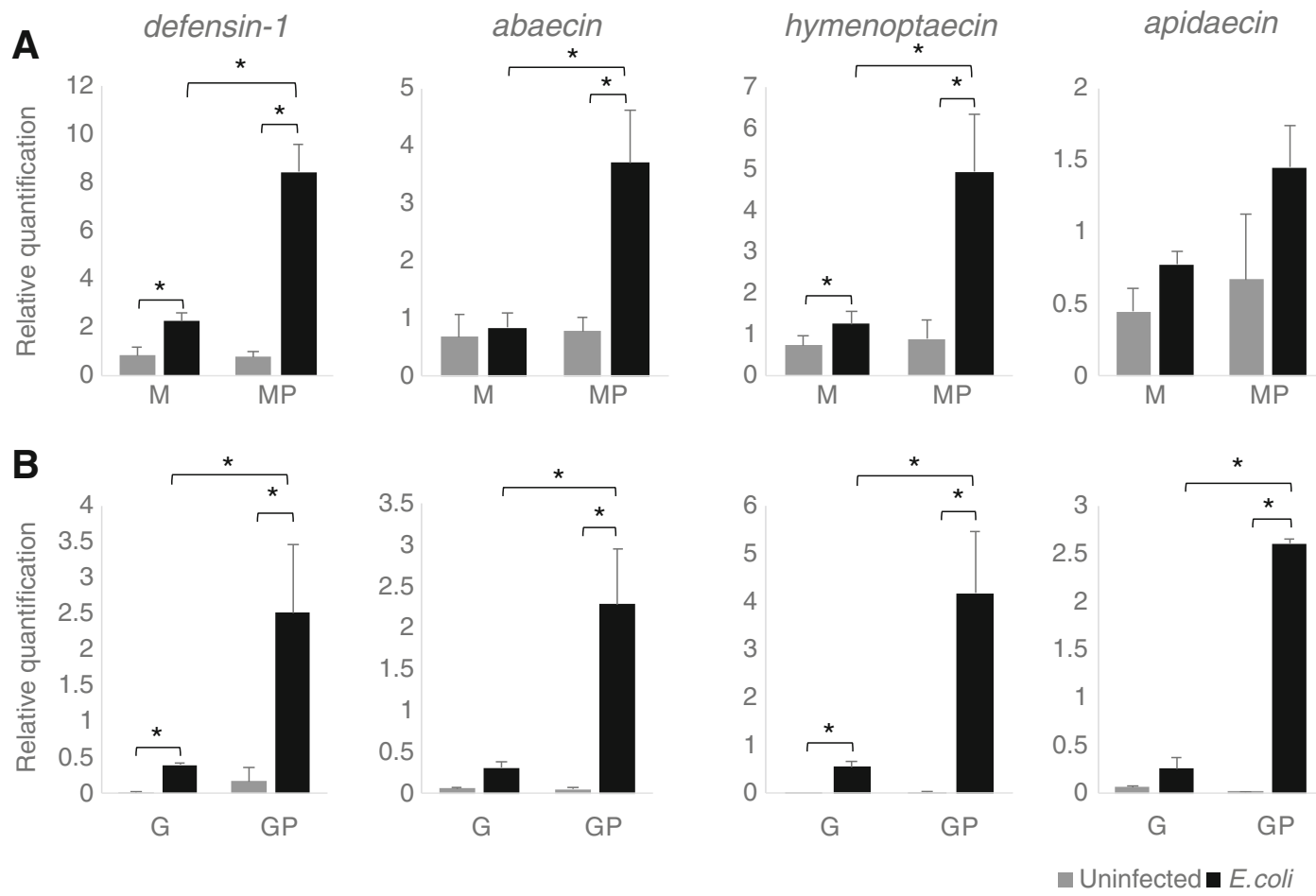

Figure 1. Expression of antimicrobial peptide genes (defensin-1, abaecin, hymenoptaecin, and apidaecin) in the fat body of worker bees fed with the pollen substitute diets Megabee (M), Megabee plus propolis (MP), Glutenose (G) or Glutenose plus propolis (GP) for 7 days. Megabee is a non-soy commercial diet produced in the USA and Glutenose is a diet developed in our laboratory consisting of soybean, corn, and corn gluten meal, plus sugar cane alcohol yeast (see materials and methods). The bees were then injected with $E$. coli, or not (uninfected). Relative expression levels after $12 \mathrm{~h}$ were assessed by RT-qPCR and were normalized to rpl32 expression. Each column represents a mean of three samples, each including three individuals. All values are given as the mean $\pm \mathrm{SEM}$. *Significant up-regulation (Wilcoxon signed-rank test; $P<0.05$ ). 
infected bees were no longer significant (Fig. 1; Binomial test, $P>0.5$ ).

In a comparison of the two diets, consumption was not significantly different in the cage tests, both with and without propolis (Table I; Wilcoxon $\mathrm{W}=19$ and 8 , respectively, $P>0.05$ ). However, addition of propolis significantly increased consumption of both Megabee and Glutenose diets (Table I; Wilcoxon $\mathrm{W}=2$ and 4, respectively; $P<0.05)$. These consumption tests were made with uninfected bees.

\section{DISCUSSION}

Providing a natural protein diet, such as bee bread, sustains activation of the immune system in honey bees (Alaux et al. 2010). Initially, our objective was to determine if an artificial protein diet would also permit immune system activation. We injected bees with E. coli and found that this stimulation increased immune gene expression. The injection procedure itself could have provoked some or all of this increase (Lourenço et al. 2013). However, since injection with $E$. coli did give a measurable immune gene expression response, as also reported by CasteelsJosson et al. (1994), we considered it a valid means to test how diet could affect such a response.

Table I. Consumption in grams of Megabee (M) and Glutenose $(\mathrm{G})$ protein diets with $(+\mathrm{P})$ or without propolis extract by groups of 100 bees in cages. Each value in the table is the consumption in grams during $48 \mathrm{~h}$.

\begin{tabular}{lcccc}
\hline Repetition & $\mathrm{M}$ & $\mathrm{M}+\mathrm{P}$ & $\mathrm{G}$ & $\mathrm{G}+\mathrm{P}$ \\
\hline 1 & 0.9734 & 1.0193 & 0.8543 & 0.6492 \\
2 & 0.9839 & 0.9842 & 0.9646 & 1.1420 \\
3 & 0.8279 & 1.2854 & 0.1329 & 0.9412 \\
4 & 0.9958 & 1.2145 & 0.9587 & 1.2568 \\
5 & 0.9645 & 1.5540 & 0.9466 & 1.2358 \\
6 & 0.8178 & 0.8954 & 0.1289 & 0.9865 \\
7 & 0.9711 & 1.0178 & 1.0114 & 1.2547 \\
8 & 0.9821 & 0.9785 & 1.0030 & 1.1230 \\
9 & 0.8187 & 0.8263 & 0.5412 & 0.7452 \\
mean & 0.9261 & 1.0861 & 0.7268 & 1.0371 \\
\hline
\end{tabular}

Bees injected with E. coli that had been fed these diets without propolis had higher expression of all four AMP genes, though the differences were significant for only two of the genes. In comparison, Lourenço et al. (2013) found significantly higher expression of all three analyzed genes (defensin-1, abaecin, and hymenoptaecin) in bees challenged with bacteria that had been fed a natural diet of bee bread; besides a possible effect of the diets, our analysis may have been hampered by the small sample size.

As we were aware that bee diet manufacturers and beekeepers often include diet additives in their formulations in an attempt to improve bee health, in addition to testing the artificial diets, we decided to test whether such an additive would affect the immune system. As a candidate additive, we chose propolis because of its known importance for bee health (Borba 2015) and because some beekeepers in the USA were already using it.

There was no significant increase in immune gene expression due to the addition of propolis to the diet in uninfected bees; however, in the infected bees, antimicrobial protein gene expression was greatly increased in bees that had been fed the diet that contained $0.1 \%$ propolis. The immune system is apparently lowly expressed when there is no infection; it becomes activated when bacteria are injected (Fig. 1). Activation of immune system genes only after infection conserves energy (Evans and Pettis 2005; Laughton et al. 2011; Moret and Schmid-Hempel 2000).

Adding propolis to the diet did not result in increased immune gene expression in uninfected bees. Honey bee immune genes should only be expressed when needed because production of storage proteins such as vitellogenin is correspondingly reduced when infection stimulates immune gene expression (Lourenco et al. 2009), which negatively affects longevity and brood rearing capacity (Amdam et al. 2003, 2004; Smart et al. 2016). Associative learning (Mallon et al. 2003) and social interactions in honey bees (Richard et al. 2008) can also be affected by stimulation of the immune system. Bacteria pathogenic for bees, 
such as Paenibacillus larvae, also cause an increase in immune gene expression in bee larvae when infected orally (Decanini et al. 2007; Evans 2004). Bees injected with the Gram-negative bacterium Serratia marcescens or the Gram-positive bacterium Micrococcus luteus have increased expression of immune response genes (Lourenço et al. 2013).

In our investigation, adding propolis to the food greatly increased immune gene expression in bees injected with E. coli, compared to the uninfected bees (same diets without propolis). This brings new insight into a possible role of propolis in reducing colony susceptibility to pathogens. It is unknown whether bees would normally ingest propolis; however, our findings lead us to hypothesize that they do so when challenged with pathogens. In a similar fashion, honey bees infected with the microsporidian gut parasite Nosema ceranae preferably consumed medicinal honeys (Gherman et al. 2014). Also, increased resin collection after infection with the fungal pathogen Ascosphaera apis was considered self-medication at the colony level (Simone-Finstrom and Spivak 2012). Uninfected bees fed Megabee without propolis showed significant higher transcript levels of the antimicrobial genes than uninfected bees fed the Glutenose diet without propolis. Possibly, the Megabee formulation includes substances that stimulate immune gene expression, even in uninfected bees. This could be a negative attribute, because it would entail unnecessary metabolic costs. It would be more efficient to activate the immune system only when needed.

Our uninfected bees fed propolis did not have significantly altered immune gene expression compared to bees fed the same diet without propolis. It has been found that applying propolis to the inside of hives allows decreased investment in immune function through reduced immune gene expression in uninfected adult worker bees (Borba et al. 2015; Simone et al. 2009); however, in those investigations it is not known whether the bees consumed propolis or how the bees exposed to propolis would react if infected.
Possibly, the bees in the hives with added propolis were less challenged by bacteria than those that had no added propolis, which could react to the bacteria by increasing immune gene expression. The apparent decreased investment could be the normal situation, when there is ample propolis, which is altered when there is less propolis. Conifer resin has also been found to decrease activation of the immune system in wood ants (Castella et al. 2008).

The propolis was added in an ethanol solution. Ethanol has been found to provoke behavioral changes in honey bees (Abramson et al. 2004; Mustard et al. 2008), as well as physiological stress (Hranitz et al. 2010). We used ethanol extracts because they are inexpensive to prepare and would be more accessible to beekeepers. The amount of ethanol in the diet was quite small $(1 \%)$, and at the incubator temperature of $34^{\circ} \mathrm{C}$, much of it evaporated quickly. In previous investigations on the effect of ethanol, effects were only found at concentrations of $5 \%$ ethanol or more (Sokolowski et al. 2012; Hranitz et al. 2010).

Other researchers have also found that oral feeding of bees with propolis or propolisrelated compounds can positively impact on their health. Stingless bee propolis can help control the fungal bee pathogen, Nosema ceranae (Suwannapong et al. 2011; Yemor et al. 2015). Toxicity of mycotoxins is ameliorated by propolis (Niu et al. 2011).

Selection for increased propolis production by honey bees has been associated with improved brood viability, lifespan and hygienic behavior (Nicodemo et al. 2013, 2014). Additionally, when added to bacterial media, propolis and its components have been found to inhibit the growth of an important bacterial bee pathogen, Paenibacillus larvae, which causes the brood disease American Foulbrood (Bastos et al. 2008; Bilikova et al. 2013). Various investigators have found that propolis inhibits the growth of bee pathogens in vitro, implying that bees could use it for self-medication, though beneficial effects through stimulation of the immune system had only been speculated (Antunez et al. 2008; 
Bastos et al. 2008; Borba et al. 2015; Erler and Moritz 2016).

Based on our findings, propolis appears to be important for the induction of full expression of the immune system response in bees challenged with bacteria. Consequently, its role in maintaining healthy colonies should be reexamined. Our study shows that propolis extract added to artificial protein diets $(0.1 \%$ propolis solids in the final mixture) greatly increases (mean of over fivefold) the expression of immune system (AMP) genes in honey bees challenged with injections of bacteria. We used Brazilian green propolis, which is widely recognized and valued for its health properties (Bastos et al. 2008; Gao et al. 2014; Farnesi et al. 2009; Frion-Herrera et al. 2015; Santos et al. 2002). It will be useful to test other types of propolis in the same system, investigate dose-dependency and determine if feeding propolis gives protection against honey bee pathogens, including viruses, which are considered to be important causes of honey bee losses throughout the world (Cornman et al. 2012). Adding propolis to hives has been found to reduce the increase in deformed wing virus titers in honey bee colonies; colonies with added propolis were also significantly stronger than propolis-removed colonies (Drescher et al. 2017). These findings indicate that propolis can interfere with the dynamics of Varroa destructor-transmitted viruses; though the mechanism through which propolis impacted on virus infection was not investigated. An important consideration when adding antimicrobials to a bee diet, whether they be natural or artificial, is how they may affect the normal microflora in the bee gut (Anderson et al. 2011; Tian et al. 2012).

Beekeepers, bee diet manufacturers, and researchers often add natural oils and other substances to pollen substitutes in an attempt to improve the health of honey bee colonies (Gende et al. 2009; Emsen and Dodologlu 2015). However, it is difficult to objectively measure the efficiency of such supplements in improving bee health. The bioassay that we employed here could help screen for substances that are beneficial.

\section{ACKNOWLEDGEMENTS}

We thank the Genetics Department of the Ribeirão Preto School of Medicine of the University of São Paulo for apiary and lab facilities. Zilá L. P. Simões and Marcia G. Bitondi provided support and access to the facilities of the University of São Paulo Bee Development Biology Laboratory. Karina R. Guidugli aided in the molecular analyses. Rogerio Pereira, Joyce Mayra Volpini de Almeida, and Luiz Aguiar helped with colony maintenance and collected material. Marcela Laure helped develop the dissection techniques and trained A.P.T. Tatiana Reis Icuma of the Biostatistics Service of the Ribeirao Preto School of Medicine of the University of São Paulo helped with the statistical analysis. US beekeepers David Miksa, David Mendes, and Robert Meise shared information about pollen substitute diets and beekeeping management that motivated this research. Gordon Wardell participated in discussions about bee diet development and provided Megabee diet samples.

Author contributions D.D.J. and A.P.T. conceived and planned the project on the effect of artificial diets and propolis on bee health. A.P.T. did the lab work, under the guidance of A.P.L. and D.D.J. A.P.T. and A.P.L. made the molecular analyses. D.D.J., A.P.T., and A.P.L. made the statistical analyses. A.P.L. prepared Fig. 1. D.D.J., A.P.T., and A.P.L. wrote the paper.

\section{Funding}

This work was supported by the Brazilian government funding agencies, Coordenação de Aperfeiçoamento de Pessoal de Nível Superior (CAPES) and the Conselho Nacional de Desenvolvimento Científico e Tecnológico (CNPq) and by the Fundação de Apoio ao Ensino, Pesquisa e Assistência (FAEPA), a non-profit foundation of the teaching hospital of the Ribeirão Preto Medical School of the University of São Paulo.

\section{COMPLIANCE WITH ETHICAL STANDARDS}

Competing interests The authors declare that they have no potential conflict of interest in relation to the study in this paper. 
La consommation de propolis amplifie la réponse immunitaire chez des abeilles infectées par des bactéries

\section{Apis mellifera / peptides antimicrobiens / substitut au pollen / expression génique / santé des abeilles}

\section{Die Aufnahme von Propolis mit der Nahrung steigert die Immunantwort bei bakteriell infizierten Bienen}

\section{Apis mellifera / antimikrobiale Peptide / Pollenersatz / Genexpression / Bienengesundheit}

\section{REFERENCES}

Abramson, C.I., Place, A.J., Aquino, I.S., Fernandez, A. (2004) Development of an ethanol model using social insects: IV. Influence of ethanol on the aggression of Africanized honey bees (Apis mellifera L.). Psychol. Rep. 94 (3 Pt 2), 1107-15

Alaux, C., Ducloz, F., Crauser, D, Le Conte, Y. (2010) Diet effects on honeybee immune competence. Biol. Lett. 6 (4), 562-565

Amdam, G.V., Norberg, K., Hagen, A., Omholt, S.W. (2003) Social exploitation of vitellogenin. Proc. Natl. Acad. Sci. 100 (4), 1799-1802

Amdam, G.V., Simões, Z.L., Hagen, A., Norberg, K., Schrøder, K., Mikkelsen, Ø., Kirkwood, T.B., Omholt, S.W. (2004) Hormonal control of the yolk precursor vitellogenin regulates immune function and longevity in honeybees. Exp. Gerontol. 39(5), 767-773

Anderson, K.E., Sheehan, T.H., Eckholm, B.J., Mott, B.M., DeGrandi-Hoffman, G. (2011) An emerging paradigm of colony health: Microbial balance of the honey bee and hive (Apis mellifera). Insectes Soc. 58(4), 431444

Antunez, K., Harriet, J., Gende, L., Maggi, M., Eguaras, M., Zunino, P. (2008) Efficacy of natural propolis extract in the control of American Foulbrood. Vet. Microbiol. 131 (3-4), 324-331

Bastos, E., Simone, M., Jorge, D.M., Soares, A.E., Spivak, M. (2008) In vitro study of the antimicrobial activity of Brazilian propolis against Paenibacillus larvae. J. Invertebr. Pathol. 97 (3), 273-281

Bauer, D.M., Wing, I.S. (2016) The macroeconomic cost of catastrophic pollinator declines. Ecol. Econ. 126, 1-13

Bilikova, K., Popova, M., Trusheva, B., Bankova, V. (2013) New anti-Paenibacillus larvae substances purified from propolis. Apidologie 44 (3), 278-285

Borba, R.S. (2015). Constitutive and therapeutic benefits of plant resins and a propolis envelope to honey bee, Apis mellifera L., immunity and health. Ph.D. thesis. University of Minnesota.

Borba, R.S., Klyczek, K.K., Mogen, K.L., Spivak, M. (2015) Seasonal benefits of a natural propolis envelope to honey bee immunity and colony health. J. Exp. Biol. 218 (22), 3689-3699

Casteels-Josson, K., Zhang, W., Capaci, T., Casteels, P., Tempst, P. (1994) Acute transcriptional response of the honeybee peptide-antibiotics gene repertoire and required post-translational conversion of the precursor structures. J. Biol. Chem. 269 (46), 28569-28575

Castella, G., Chapuisat, M., Moret, Y., Christe, P. (2008) The presence of conifer resin decreases the use of the immune system in wood ants. Ecol. Entomol. 33(3), 408-412.

Chopra, S.S., Bakshi, B.R., Khanna V. (2015) Economic Dependence of U.S. Industrial Sectors on AnimalMediated Pollination Service. Environ. Sci. Technol. 49 (24), 14441-14451

Cornman, R.S., Tarpy, D.R., Chen, Y., Jeffreys, L., Lopez, D., Pettis, J.S., vanEngelsdorp, D., Evans, J.D. (2012) Pathogen webs in collapsing honey bee colonies. PLoS ONE 7 (8), e43562

Cremer, S., Armitage, S.A.O., Schmid-Hempel, P. (2007) Social Immunity. Curr. Biol. 17 (16), 693-702

Daniel, W.W. (1978) Applied nonparametric statistics. Houghton Miflin Company, Boston

De Jong, D. (1996) Africanized honey bees in Brazil, forty years of adaptation and success. Bee World 77 (2), 6770

Decanini, L.I., Collins, A.M., Evans, J.D. (2007) Variation and heritability in immune gene expression by diseased honeybees. J. Hered. 98 (3), 195-201

DeGrandi-Hoffman, G., Chen, Y. (2015) Nutrition, immunity and viral infections in honey bees. Curr. Opin. Insect Sci. 10, 170-176

Drescher, N., Klein, A.-M., Neumann, P., Yañez, O., Leonhardt, S. (2017) Inside honeybee hives: Impact of natural propolis on the ectoparasitic mite Varroa destructor and viruses. Insects 8(1), E15

Emsen, B., Dodologlu, A. (2015) The efficacy of thymol and oxalic acid in bee cake against bee mite (Varroa destructor Anderson \& Trueman) in honey bee (Apis mellifera L.) colonies. Kafkas Univ. Vet. Fak. Derg. 21 (1), 45-48

Erler, S., Moritz, R.F.A. (2016) Pharmacophagy and pharmacophory: mechanisms of self-medication and disease prevention in the honeybee colony (Apis mellifera ). Apidologie 47 (3), 389-411

Evans, J.D. (2004) Transcriptional immune responses by honey bee larvae during invasion by the bacterial pathogen, Paenibacillus larvae. J. Invertebr. Pathol. 85 (2), $105-111$

Evans, J.D., Aronstein, K., Chen, Y.P., Hetru, C., Imler, J.L., Jiang, H., Kanost, M., Thompson, G.J, Zou, Z., Hultmark, D. (2006) Immune pathways and defence mechanisms in honey bees Apis mellifera. Insect Mol. Biol. 15(5), 645-656

Evans, J.D., Pettis, J.S. (2005) Colony-level impacts of immune responsiveness in honey bees, Apis mellifera . Evolution 59(10), 2270-2274 
Evans, J.D., Spivak, M. (2010) Socialized medicine: individual and communal disease barriers in honey bees. J. Invertebr. Pathol. 103, S62-S72

Farnesi, A.P., Aquino-Ferreira, R., De Jong, D., Bastos, J.K., Soares, A.E. (2009) Effects of stingless bee and honey bee propolis on four species of bacteria. Genet. Mol. Res. 8 (2), 635-640

Frion-Herrera, Y., Diaz-Garcia, A., Ruiz-Fuentes, J., Sforcin, J.M. (2015) Brazilian green propolis induced apoptosis in human lung cancer A549 cells through mitochondrial-mediated pathway. J. Pharm. Pharmacol. 67 (10), 1448-1456

Gao, W., Wu, J., Wei, J., Pu, L., Guo, C., Yang, J., Yang, M., Luo, H. (2014) Brazilian green propolis improves immune function in aged mice. J. Clin. Biochem. Nutr. 55 (1), 7-10

Gende, L.B., Maggi, M.D., Damiani, N., Fritz, R., Eguaras, M.J., Floris, I. (2009) Advances in the apiary control of the honeybee American Foulbrood with Cinnamon (Cinnamomum zeylanicum) essential oil. Bull. Insectology 62 (1), 93-97

Gherman, B.I., Denner, A., Bobis, O., Dezmirean, D.S., Mărghitaş, L.S., Schlüns, H., Moritz, R.F.A., Erler, S. (2014) Pathogen-associated self-medication behavior in the honeybee Apis mellifera. Behav. Ecol. Sociobiol. 68(11), 1777-1784

Hranitz, J.M., Abramson, C.I., Carter, R.P. (2010) Ethanol increases HSP70 concentrations in honeybee (Apis mellifera L.) brain tissue. Alcohol 44 (3), 275-82

Imdorf, A., Bogdanov, S., Ochoa R.I., Calderone, N.W. (1999) Use of essential oils for the control of Varroa jacobsoni in honey bee colonies. Apidologie 30:209-229.

Laughton, A.M., Boots, M., Siva-Jothy, M.T. (2011) The ontogeny of immunity in the honey bee, Apis mellifera L. following an immune challenge. J. Insect Physiol. 57 (7), 1023-1032

Lourenço, A.P., Guidugli-Lazzarini, K.R., Freitas, F.C.P., Bitondi, M.M.G., Simões, Z.L.P. (2013) Bacterial infection activates the immune system response and dysregulates microRNA expression in honey bees. Insect Biochem. Molec. Biol. 43 (5), 474-482

Lourenço, A.P., Mackert, A., Cristino, A.S., Simões, Z.L.P. (2008) Validation of reference genes for gene expression studies in the honey bee, Apis mellifera, by quantitative real-time RT-PCR. Apidologie 39 (3), 372-385

Lourenco, A.P., Martins, J.R., Bitondi, M.M.G., Simoes, Z.L.P. (2009) Trade-off between immune stimulation and expression of storage protein genes. Arch. Insect Biochem. Physiol. 71 (2), 70-87

Mallon, E.B., Brockmann, A., Schmid-Hempel, P. (2003) Immune response inhibits associative learning in insects. Proc. Biol. Sci. 270 (1532), 2471-2473

Moret, Y., Schmid-Hempel, P. (2000) Survival for immunity: The price of immune system activation for bumblebee workers. Science, 290 (5494), 1166-1168
Morse, R.A. (1975) Bees and Beekeeping. Cornell University Press, Ithaca

Mustard, J.A., Edgar, E.A., Mazade, R.E., Wu, C., Lillvis, J.L., Wright, G.A. (2008) Acute ethanol ingestion impairs appetitive olfactory learning and odor discrimination in the honey bee. Neurobiol. Learn. Mem. 90 (4), 633-43.

Neumann, P., Carreck, N.L. (2010) Honey bee colony losses. J. Apic. Res. 49(1), 1-6

Nicodemo, D., De Jong, D., Couto, R.H.N., Malheiros, E.B. (2013) Honey bee lines selected for high propolis production also have superior hygienic behavior and increased honey and pollen stores. Genet. Mol. Res. 12 (4), 6931-6938

Nicodemo, D., Malheiros, E.B., De Jong, D., Couto, R.H.N. (2014) Increased brood viability and longer lifespan of honeybees selected for propolis production. Apidologie 45 (2), 269-275

Niu, G., Johnson, R.M., Berenbaum, M.R. (2011) Toxicity of mycotoxins to honeybees and its amelioration by propolis. Apidologie 42 (1), 79-87.

R Core Team (2013). R: A language and environment for statistical computing. R Foundation for Statistical Computing, Vienna, Austria. URL http://www.R-project.org/.

Richard, F.J., Aubert, A., Grozinger, C.M. (2008) Modulation of social interactions by immune stimulation in honey bee, Apis mellifera, workers. BMC Biology 6 , 50

Rosenkranz, P. (1999) Honey bee (Apis mellifera L.) tolerance to Varroa jacobsoni Oud. in South America. Apidologie 30 (2-3), 159-172

Santos, F.A., Bastos, E.M.A., Uzeda, M., Carvalho, M.A., Farias, L.M., Moreira, E.S., Braga, F.C. (2002) Antibacterial activity of Brazilian propolis and fractions against oral anaerobic bacteria. J. Ethnopharmacol. 80 (1), 1-7

Seeley, T.D., Morse, R.A. (1976) The nest of the honey bee (Apis mellifera L.) Insects Soc. 23 (4), 495-512

Siede, R., Meixner, M.D., Buchler R. (2012) Comparison of transcriptional changes of immune genes to experimental challenge in the honey bee (Apis mellifera). J Apic Res 51(4), 320-328

Simone, M., Evans, J.D., Spivak, M. (2009) Resin collection and social immunity in honey bees. Evolution 63 (11), 3016-3022

Simone-Finstrom M., Spivak M. (2010) Propolis and bee health: the natural history and significance of resin use by honey bees. Apidologie 41 (3), 295-311

Simone-Finstrom, M.D., Spivak, M. (2012) Increased Resin Collection after Parasite Challenge: A Case of SelfMedication in Honey Bees? PLoS ONE 7 (3), e34601.

Smart, M., Pettis, J., Rice, N., Browning, Z., Spivak, M. (2016) Linking measures of colony and individual honey bee health to survival among apiaries exposed to varying agricultural land use. PLoS ONE, 11 (3), e0152685 
Sokolowski, M.B.C., Abramson, C.I., Craig, D.P. A. (2012) Ethanol Self-Administration in Free-Flying Honeybees (Apis mellifera L.) in an Operant Conditioning Protocol. Alcohol Clin. Exp. Res. 36 (9), 1568-1577

Suwannapong, G., Maksong, S., Benbow, M. (2011) Stingless bee propolis effects on experimental infection of Apis florea with Nosema ceranae. J. Agric. Sci. Technol. A 1, 818-825

Tian, B., Fadhil, N.H., Powell, J.E., Kwong, W.K., Moran, N.A. (2012) Long-term exposure to antibiotics has caused accumulation of resistance determinants in the gut microbiota of honeybees. MBio, 3 (6), e00377-12
vanEngelsdorp, D., Evans, J.D., Saegerman, C., Mullin, C., Haubruge, E. et al. (2009) Colony Collapse Disorder: A Descriptive Study. PloS ONE 4 (8), e6481

Visscher, P.K. (1980) Adaptations of honey bees (Apis mellifera) to problems of nest hygiene. Sociobiology 5(3), 249-260

Wilson-Rich, N., Spivak, M., Fefferman, N.H., Starks, P.T. (2009) Genetic, individual, and group facilitation of disease resistance in insect societies. Annu. Rev. Entomol. 54, 405-423

Yemor, T., Phiancharoen, M., Benbow, M.E., Suwannapong, G. (2015) Effects of stingless bee propolis on Nosema ceranae infected Asian honey bees, Apis cerana. J. Apic. Res. 54 (5), 468-473 